\title{
Perlindungan Hukum terhadap Notaris Penerima Protokol: Bentuk dan Batasan
}

\author{
Yetniwati ${ }^{\star}$, Taufik Yahya, Diana Amir \\ Fakultas Hukum Universitas Jambi \\ *yetniwatisamad@yahoo.co.id
}

\begin{abstract}
A notary is a public official authorized to draw up and keep authentic deeds and other documents permitted by laws and regulations. Whenever a notary dies, or reaches retirement age, changes his/her domicile or profession, he/she shall submit his/her retired notary protocol to another notary appointed by the Regional Supervisory Council. The submission of notary protocol is regulated in Article 65 of the Law on Notary Positions, yet without legal protection. In some cases, court decisions are found to have imposed sanctions upon a notary who received the protocol despite the mistake of the notary protocol giver. This article encourages that the notary who receives the protocol be provided with legal protection, because he/she is only the party who receives the protocol made by another notary. The imposition of responsibility upon the notary protocol recipient regarding the contents of the deed he/she keeps will only lead to injustice and legal uncertainty. Since no regulation has been provided concerning to such matter, it is necessary to afford legal protection which comprises: the responsibility of the heirs of the notary (giver); the limitation of the responsibility of the protocol recipient; the limitation of protocol retention time; and the necessity of storing notary protocols in the form of microfilm. Nevertheless, the notary protocol recipient shall also have limited protection, in the sense that he/she can be held accountable with respect to the obligation to keep the notary protocol he/she receives in proper ways.
\end{abstract}

Keywords: notary; protocol recipent; deed depository; legal protection. 


\begin{abstract}
Abstrak
Notaris adalah pejabat umum yang berwenang membuat dan menyimpan akta dalam bentuk akta otentik, serta dokumen lain yang diperbolehkan oleh perundang-undangan. Setiap notaris yang meninggal dunia, mencapai usia pensiun, pindah domisili, atau pindah profesi, wajib menyerahkan protokol notarisnya kepada notaris lain yang ditunjuk oleh Majelis Pengawas Daerah. Pengaturan penyerahan protokol notaris diatur dalam Pasal 65 Undangundang Jabatan Notaris, namun tidak dengan perlindungan hukumnya. Dalam beberapa kasus dijumpai putusan pengadilan yang memberikan sanksi kepada notaris penerima protokol sekalipun berkaitan dengan kesalahan notaris pemberi protokol. Artikel ini mendorong agar notaris penerima protokol mendapatkan perlindungan hukum, sebab ia hanya sebagai pihak yang menerima protokol yang dibuat oleh notaris lainnya. Pembebanan tanggung jawab kepada notaris penerima protokol terkait isi akta yang disimpannya justru akan menyebabkan ketidakadilan dan ketidakpastian hukum. Oleh karena sejauh ini belum ada pengaturannya, maka perlu diupayakan perlindungan hukum yang meliputi: tanggung jawab ahli waris notaris (pemberi); batasan tanggung jawab penerima protokol; batasan waktu penyimpanan protokol; dan keharusan penyimpanan protokol notaris dalam bentuk mikrofilm. Meski demikian, notaris penerima protokol tentu harus pula dibatasi perlindungannya, dalam artian dapat dimintai pertanggungjawabannya, yaitu dalam hal keharusannya menyimpan protokol notaris yang diterimanya secara patut.
\end{abstract}

Kata kunci: notaris; penerima protokol; penyimpanan akta; perlindungan hukum.

\title{
A. Pendahuluan
}

Artikel ini membahas perlindungan hukum bagi notaris penerima protokol. Protokol notaris adalah kumpulan dokumen yang merupakan arsip negara yang harus disimpan dan dipelihara notaris. ${ }^{1}$ Protokol demikian itu, yang harus disimpan dan dipelihara oleh notaris, tidak selalu merupakan dokumen dari dirinya sendiri, melainkan juga bisa berasal dari notaris lain yang diterimanya berdasarkan

1 Undang-undang Nomor 30 Tahun 2004 tentang Jabatan Notaris, Pasal 1 angka 13. 
penyerahan dari Majelis Pengawas Daerah. Dalam artikel ini dibahas, dalam hal notaris menerima protokol dari notaris lainnya, bagaimana sebenarnya bentuk dan batasan perlindungan hukumnya, mengingat ia hanya menerima apa yang diserahkan kepadanya.

Pembahasan tentang perlindungan hukum terhadap notaris penerima protokol ini penting dilakukan setidaknya karena dua alasan. Pertama, profesi notaris merupakan profesi pejabat publik dalam lapangan hukum privat. Ia menjadi profesi pejabat umum atau publik karena berwenang untuk membuat perjanjian akta autentik dan kewenangan lainnya yang diberikan undang-undang. Kedudukannya di tengah-tengah masyarakat dalam pembuatan akta tersebut sekaligus kekuatan pembuktian dari akta yang dibuatnya, menyebabkan jabatan ini sebagai jabatan kepercayaan, yang harus dilaksanakan dengan menjunjung tinggi etika hukum, martabat serta keluhurannya. ${ }^{2}$ Karena kedudukan dan peran yang penting itu, ${ }^{3}$ sehingga profesi notaris dapat dikategorikan sebagai profesi atau jabatan mulia (nobile officium), disebabkan perannya sangat erat hubungannya dengan kemanusiaan. ${ }^{4}$

Sebagaimana ketentuan Undang-undang Jabatan Notaris (UUJN), baik Undang-undang Nomor 30 Tahun 2004 (UUJN Tahun 2004) maupun perubahannya yaitu Undang-undang Nomor 2 Tahun

2 Edwar, Faisal A. Rani, dan Dahlan Ali, "Kedudukan Notaris sebagai Pejabat Umum Ditinjau dari Konsep Equality Before the Law”, Jurnal Hukum \& Pembangunan, 49, 1 (2019), hlm. 181.

3 Kedudukan dan peran penting ini terkait kedudukan dan kewenangannya dalam membantu dan menciptakan kepastian serta perlindungan hukum bagi masyarakat. Akta yang dibuatnya merupakan suatu bentuk pencegahan apabila terjadi masalah hukum, sekaligus suatu bingkai perbuatan hukum yang dapat dipergunakan sebagai alat bukti yang sempurna. Aris Yulia, "Profesi Notaris di Era Industrialisasi dalam Perspektif Transendensi Pancasila”, Law and Justice, 4, 1 (2019), hlm. 65.

4 Penyebutan notaris sebagai profesi atau pejabat mulia dilandasi alasan bahwa akta yang dibuatnya sesungguhnya dapat menjadi dasar hukum atas status harta benda, hak dan kewajiban seseorang. Kekeliruan atas akta yang dibuatnya dapat menyebabkan tercabutnya hak seseorang dan terbebaninya seseorang atas suatu kewajiban. Tengku Erwinsyahbana dan Melinda, "Kewenangan dan Tanggung Jawab Notaris Pengganti setelah Pelaksanaan Tugas dan Jabatan Berakhir”, Lentera Hukum, 5, 2 (2018), hlm. 324. 
2014 (UUJN Tahun 2014), notaris selain mempunyai kewenangan membuat akta, ${ }^{5}$ juga punya kewajiban menyimpan protokol notaris. ${ }^{6}$ Protokol notaris yang disimpan merupakan dokomen yang lazim dibuat dalam bentuk tertulis. Kewajiban penyimpan protokol notaris berlangsung sampai akhir hayatnya, kecuali ditentukan lain oleh undang-undang.

Protokol yang ada pada notaris tersebut bisa saja beralih kepada notaris lainnya. Peralihan protokol dari satu notaris (pemberi) kepada notaris lainnya (penerima) bisa disebabkan karena notaris meninggal dunia, berakhir masa jabatannya, permintaan sendiri, tidak mampu secara rohani dan/atau jasmani untuk melaksanakan tugas secara terus menerus lebih dari tiga tahun, diangkat menjadi pejabat negara, pindah wilayah jabatan, diberhentikan sementara, atau diberhentikan

5 Pasal 1 angka 6 UUJN Tahun 2014, ketentuan perubahan Pasal 15 UUJN Tahun 2004, yang ayat (1) menjadi: "Notaris berwenang membuat akta autentik mengenai semua perbuatan, perjanjian, dan penetapan yang diharuskan oleh peraturan perundang-undangan dan/atau yang dikehendaki oleh yang berkepentingan untuk dinyatakan dalam akta autentik, menjamin kepastian tanggal pembuatan akta, menyimpan akta, memberikan grosse, salinan dan kutipan akta, semuanya itu sepanjang pembuatan akta itu tidak juga ditugaskan atau dikecualikan kepada pejabat lain atau orang lain yang ditetapkan oleh undang-undang”. Ayat (2) dari Pasal 15 sekarang berbunyi: "mengesahkan tanda tangan dan menetapkan kepastian tanggal surat di bawah tangan dengan mendaftar dalam buku khusus; membukukan surat di bawah tangan dengan mendaftar dalam buku khusus; membuat kopi dari asli surat di bawah tangan berupa salinan yang memuat uraian sebagaimana ditulis dan digambarkan dalam surat yang bersangkutan; melakukan pengesahan kecocokan fotokopi dengan surat aslinya; memberikan penyuluhan hukum sehubungan dengan pembuatan akta; membuat akta yang berkaitan dengan pertanahan; atau membuat akta risalah lelang”.

6 Pasal 1 angka 6 UUJN Tahun 2014, ketentuan perubahan Pasal 16 UUJN Tahun 2004, pada ayat (1) huruf b menjadi: "membuat akta dalam bentuk minuta akta dan menyimpannya sebagai bagian dari protokol notaris. Protokol notaris menurut Pasal 62 UUJN Tahun 2004 terdiri dari: minuta akta; buku daftar akta atau repertorium; buku daftar akta di bawah tangan yang penandatanganannya dilakukan di hadapan notaris atau akta di bawah tangan yang didaftar; buku daftar nama penghadap atau klapper; buku daftar protes; buku daftar wasiat; dan buku daftar lain yang harus disimpan oleh notaris berdasarkan ketentuan peraturan perundang-undangan. 
tidak hormat. ${ }^{7}$ Karena alasan tersebut, maka semua protokol harus diserahkan kepada notaris lain yang ditunjuk oleh Majelis Pengawas Daerah (MPD). Notaris lainnya sebagai penerima ini terdiri dari pejabat sementara notaris dan notaris pengganti. ${ }^{8}$ Kedua jenis jabatan notaris ini hanyalah sementara, untuk menerima protokol dari notaris yang cuti paling lama lima tahun, atau menerima protokol 12 tahun selama masa jabatannya sebagai notaris. Dalam realitanya, notaris penerima protokol bahkan menyimpan lebih dari 12 tahun.

Kedua, pengaturan bentuk perlindungan hukum dalam peralihan protokol notaris dan batasannya sangat diperlukan untuk mewujudkan keadilan dan kepastian hukum. Dengan begitu akan diketahui kapan dan dalam bentuk apa notaris penerima protokol dilindungi, serta kapan dan dalam hal apa pula ia harus turut bertanggung jawab. Hal ini penting karena dalam beberapa kasus, notaris penerima protokol dinyatakan pula ikut bertanggung jawab atas keabsahan akta yang disimpannya. Pada putusan Pengadilan Tinggi Jambi Nomor 22/PDT/2012/PT.JBI misalnya, notaris penerima protokol dinyatakan ikut bertanggung jawab atas pembatalan akta notaris yang diterimanya, dengan hukuman membayar uang paksa (dwangsoom) kepada penggugat. ${ }^{9}$ Putusan semacam ini memunculkan pertanyaan, mengingat ia hanya sebagai penyimpan protokol dan tidak turut serta dalam pembuatan akta tersebut. Keabsahan berkaitan dengan akta tersebut dibuat oleh notaris terdahulu sebagai pemberi protokol, dan karenanya mestinya segala hal terkait tanggung jawab ada pada notaris

7 Pasal 63 UUJN Tahun 2014.

8 Pasal 26 UUJN Tahun 2004.

9 Putusan Pengadilan Tinggi Jambi Nomor 22/PDT/2012 / PT.JBI, 8 / 8 / 2012, perkara perdata antara Siti Muryani RRM Koesoema, dkk. lawan Saman, dkk. Pada kasus ini, Robert Faisal (notaris penerima protokol dari notaris Hasiholan Situmeang) dan Juliani Martha (notaris penerima protokol dari notaris Nani Widiawati) menjadi bagian dari tergugat dan terbanding dalam perkara pembatalan akta jual beli tanah. Oleh majelis hakim, seluruh terbanding termasuk Robert dan Juliani, masing-masing harus membayar uang paksa 100 ribu rupiah perhari kepada penggugat/pembanding, serta juga membayar biaya perkara secara tanggung renteng, yang pada tingkat banding sebesar 150 ribu rupiah. 
pembuat protokol dan bukan pada penerima protokol. ${ }^{10}$ Apabila putusan semacam ini terus berulang, maka tentu bisa berpengaruh pada keengganan notaris menerima protokol dari notaris lain.

UUJN Tahun 2004 maupun Tahun 2014 tidaklah mengatur bentuk dan batasan perlindungan hukum bagi notaris penerima protokol. Artikel ini ditulis berdasarkan bahan-bahan hukum dan diarahkan untuk mendapatkan model perlindungan hukum bagi notaris penerima protokol. Bagian pertama artikel terlebih dahulu menguraikan urgensi perlindungan hukum bagi notaris penerima protokol. Bagian berikutnya membahas bentuk perlindungan hukum bagi notaris penerima protokol. Pembahasan dilanjutkan dengan batasan perlindungan hukum. Pada bagian akhir disampaikan kesimpulan tentang bentuk dan batasan perlindungan hukum.

\section{B. Urgensi Perlindungan Hukum bagi Notaris Penerima Protokol}

Perlindungan hukum merupakan upaya memenuhi hak-hak setiap orang yang diakui dan diberikan oleh hukum, sehingga hak-hak tersebut bisa dinikmati. ${ }^{11}$ Apabila perlindungan hukum ini dikaitkan dengan tanggung jawab seseorang, maka kepentingan atau hak yang diakui atau diberikan hukum itu harus pula dikaitkan dengan tanggung jawabnya. ${ }^{12}$ Dalam kaitannya dengan tanggung jawab, maka perlindungan hukum bisa pula dimaknai sebagai pengecualian pembebanan tanggung jawab, dikarenakan pengecualian atau

10 Pemberi protokol memang hanya bertanggung jawab atas minuta akta semasa dalam penyimpannya. Jika sudah diserahkan kepada pemerima protokol, hal ini adalah tanggung jawab penerima protokol. Namun, terhadap kebenaran substansi hukum dalam minuta akta, merupakan tanggung jawab pemberi protokol. Muhammad Faisal Nasution, “Tanggung Jawab Pemberi dan Penerima Protokol Notaris terhadap Protokol Notaris yang Hilang atau Rusak” (Tesis, Universitas Sumatera Utara, Medan, 2017).

11 Satjipto Rahardjo, Ilmu Hukum (Bandung: Citra Aditya Bakti, cetakan keenam, 2006), hlm. 53-54.

12 Raffles, "Tanggung Jawab dan Perlindungan Hukum Direksi dalam Pengurusan Perseroan Terbatas”, Undang: Jurnal Hukum, 3, 1 (2020), hlm. 123-4. 
pembebasan tanggung jawab tersebut diakui atau diberikan oleh hukum.

Uraian ringkas tentang makna perlindungan hukum tersebut dalam hubungannya dengan notaris penerima protokol berarti notaris penerima protokol semestinya mendapatkan hak-hak dan kepentingannya dalam peran dan fungsinya menyimpan protokol yang diterimanya. Hak dan kepentingan tersebut ialah berkaitan dengan pengecualian dari pembebanan tanggung jawab terhadap isi atau keabsahan akta yang diterimanya, dengan catatan telah melakukan penyimpanan secara layak dan patut, mengingat ia bukan pihak yang turut serta dalam pembuatan akta yang diterimanya untuk menyimpannya. Dalam hal notaris penerima protokol dibebaskan dari tanggung jawab terhadap isi dan keabsahan akta tersebut, sementara kewajiban menyimpannya telah dilakukan secara profesional, maka ia berarti mendapatkan perlindungan hukum.

Bagi siapa pun setiap warga negara, perlindungan hukum adalah hal yang sangat penting. Pertama, adanya perlindungan hukum akan menjadikan setiap seorang dengan kedudukan apa pun menjadi aman dan nyaman dalam menjalankan aktivitasnya. Sebagaimana dikatakan Jeremy Bentham, the greates happines principle, tujuan hukum harus berguna bagi individu dan masyakat demi mencapai kebahagiaan yang sebesar-besarnya. ${ }^{13} \mathrm{Hal}$ ini dapat dimaknai bahwa hukum itu harus bermanfaat untuk mencapai kebahagiaan. Setiap orang yang melakukan kegiatan dengan iktikad baik berkeinginan agar dilindungi oleh hukum, sehingga menjadi aman dan nyaman dalam melakukan atau mengerjakannya. Begitu pula halnya bagi seorang notaris yang telah menerima protokol. Apabila protokol telah diterima sesuai dengan prosedur yang ditentukan, lalu menyimpan protokol tersebut dengan cara yang baik dan aman, dan menjaga pula kerahasiaan akta tersebut, maka semestinya notaris demikian itu mendapatkan perlindungan hukum.

Kedua, perlindungan hukum menjadi penting sebagai upaya untuk terhindar dari ketidakadilan. Terhindar dari ketidakadilan

13 Frederikus Fios, "Keadilan Hukum Jeremy Bentham dan Relevansinya bagi Praktik Hukum Kontemporer", Humaniora, 3, 1 (2012), hlm. 302. 
merupakan keinginan semua orang, karena salah satu tujuan hukum adalah untuk mewujudkan keadilan, di samping kepastian hukum dan kemanfaatan hukum. ${ }^{14}$ Keadilan sendiri memiliki beragam makna dan pemahaman yang biasanya didasarkan pada aliran filsafat atau pemikiran tertentu sesuai dengan kondisi pemikiran manusia pada waktu tertentu. Salah satu di antaranya dipahami sebagai unsur ideal, yaitu suatu cita atau ide yang terdapat dalam hukum. ${ }^{15}$

Dalam kaitannya dengan peralihan protokol notaris, maka penerima protokol notaris tentu harus mendapatkan keadilan berupa tanggung jawab sebatas kewajibannya menyimpan protokol yang dialihkan kepadanya. Sedangkan terkait isi dan keabsahan suatu akta, dikarenakan ketidakterlibatannya dalam pembuatan akta tersebut, maka sudah semestinya bukan bagian dari tanggung jawabnya. Pembebanan tanggung jawab terhadap suatu perbuatan hukum yang tidak dilakukannya bahkan tidak diketahuinya, hanya akan menyebabkan ketidakadilan.

Ketiga, notaris pemberi protokol tetap bertanggung jawab atas akta yang telah dibuatnya, meskipun karena ketentuan hukum penyimpanan akta diserahkan kepada penerima protokol. Notaris pemberi protokol tetap bertanggung jawab atas akta yang dibuatnya, tanpa ada batasan waktu, sebagaimana ketentuan Pasal 16 ayat 1 UUJN Tahun 2014. ${ }^{16}$ Meskipun protokol telah diserahkan kepada

14 Kepastian, keadilan, dan kemanfaatan merupakan nilai dasar yang menjadi tumpuan hukum, sebagaimana diungkapkan Gustav Radbruch (Satjipto Rahardjo, Biarkan Hukum Mengalir: Catatan Kritis tentang Pergulatan Manusia dan Hukum [Jakarta: Penerbit Kompas, 2008], hlm. 80). Oleh Tristam P. Moeliono dan Tanius Sebastian ("Tendensi Reduksionis dan Utilitarianis dalam Ilmu Hukum Indonesia: Membaca Ulang Filsafat Hukum Gustav Radbruch”, makalah dalam Konferensi Asosiasi Filsafat Hukum Indonesia ke-5, Solo, 17-18 November 2015), ketiga nilai dasar tersebut lebih tepat disebut sebagai tri-tujuan hukum: keadilan, kebertujuan, dan kepastian hukum, dengan titik beratnya pada penjaminan kesetaraan sebagai keadilan substansial dalam hukum.

15 Bahder Johan Nasution, "Kajian Filosofis tentang Konsep Keadilan dari Pemikiran Klasik sampai Pemikiran Modern”, Yustisia, 3, 2 (2014), hlm. 129-30.

16 Pasal 16 ayat (1 b)UUJN 2014, menetapkan : kewajiban Notaris membuat Akta dalam bentuk Minuta Akta dan menyimpannya sebagai bagian dari 
MPD ataupun penerima protokol, ia tetap bertanggung atas protokol yang dibuatnya, karena merupakan pihak yang membuat akta dan mendengar penjelasan dari para penghadap dan tentu saja lebih mengetahui kebenaran data pada isi akta. Sementara itu, penerima protokol hanya menjadi pihak yang menerima akta dan protokol yang sudah dibuat terlebih dahulu. Penerima protokol tidak begitu banyak tahu tentang penghadap, dan karenanya tidak bisa diberi tanggung jawab tentang kebenaran isi akta serta sanksi hukum, terkecuali terkait proses penyimpanan protokol sejak setelah diterimanya dari MPD.

Seorang notaris tentu akan menerima protokol dari notaris lain, karena adanya perlindungan hukum yang dapat melepaskan tanggung jawab bagi penerima protokol. Perbuatan mana yang dapat melepaskan tanggung jawab notaris sebagai penerima protokol ini perlu adanya aturan yang pasti agar ia menjadi aman dan nyaman menerima dan menyimpan protokol notaris lain. Iktikad baik seorang notaris mau menerima protokol dari notaris bukan hanya sebagai tanggung jawab moril saja, sebagaimana yang diamanatkan oleh UUJN, akan tetapi juga agar mendapatkan kemanfaatkan dari perbuatan menerima dan menyimpan protokol dari notaris lain secara baik. Karena perbuatan menerima untuk menyimpan protokol itu memerlukan tanggung jawab, sehingga memerlukan sarana penyimpanan yang baik dan aman. Karena itu perlu ada ketentuan tanggung jawab penerima protokol dan juga batasan batasan tanggung jawab tersebut. Pengalaman seorang notaris penerima protokol mengatakan, "belum tentu menerima protokol dari notaris lain akan menambah klien bagi dirinya, karena bisa saja klien dari notaris pemberi protokol untuk transaksi selanjutnya membuat suatu akta berpindah kepada notaris lain." ${ }^{17}$ Apabila tidak ada perlindungan hukum bagi penerima protokol, niscaya notaris tidak mau menerima protokol dari notaris lain yang telah meninggal, cuti, diberhentikan, alih profesi, atau usia pensiun.

Keempat, perlindungan hukum merupakan bagian dari hak

17 Wawancara dengan salah seorang notaris di Jambi, 4/8/2019. 
konstitusional yang diberikan dan dijamin Konstitusi, sebagaimana ketentuan Pasal 28 D ayat (1) dan Pasal 29 G ayat (1) Undang-undang Dasar Negara Republik Indonesia Tahun 1945. ${ }^{18}$ Dalam Undangundang Nomor 13 tahun 1999 tentang Hak Asasi Manusia (UUHAM), hak untuk mendapatkan perlindungan hukum diatur pada Pasal 3 ayat (2) dan (3) UUHAM, "setiap orang berhak atas pengakuan, jaminan, perlindungan dan perlakuan hukum yang adil serta mendapat kepastian hukum dalam semangat di depan hukum." Kemudian Pasal 3 ayat (3) UUHAM, "setiap orang berhakatas perlindungan hak asasi manusia dan kebebasan manusia, tanpa diskriminasi”. Hak atas perlindungan diakui dan dijamin oleh negara sebagai bukti bahwa perlindungan hukum bagi notaris penerima protokol merupakan harkat martabat manusia. Perlindungan hukum kepada notaris penerima protokol sudah diakui dan dijamin oleh negara, oleh sebab itu norma hukum haruslah dapat mengatur perlindungan hukum yang berkeadilan. Kepastian hukum untuk perlindungan kepada notaris penerima protokol akan mudah terwujud, adanya dasar hukum tertulis dan jelas untuk berpijak bagi penegak hukum, konsisten, sehingga dalam pelaksanaannya hukum mudah ditegakkan. Apabila hukum tidak memberikan kepastian hukum dan keadilan, niscaya tujuan hukum tidak akan tercapai.

\section{Bentuk Perlindungan Hukum bagi Notaris Penerima Protokol}

Perlindungan hukum pada umumnya dibedakan antara perlindungan hukum preventif dan represif. Perlindungan hukum preventif bertujuan untuk mencegah terjadinya sengketa, sedangkan perlindungan hukum represif bertujuan untuk menyelesaikan sengketa. ${ }^{19}$ Uraian

18 Pasal 28 D ayat (1) UUD 1945: "Setiap orang berhak atas pengakuan, jaminan, perlindungan, dan kepastian hukum yang adil serta perlakuan yang sama di hadapan hukum." Pasal 29 G ayat (1): "Setiap orang berhak atas perlindungan diri pribadi, keluarga, kehormatan, martabat, dan harta benda yang di bawah kekuasaannya, serta berhak atas rasa aman dan perlindungan dari ancaman ketakutan untuk berbuat atau tidak berbuat sesuatu yang merupakan hak asasi".

19 Demikian menurut Philipus M. Hadjon, sebagaimana dikutip Luthvi 
berikut ini, yang akan membahas bentuk perlindungan hukum bagi notaris penerima protokol, juga akan menggunakan konsep pembedaan perlindungan hukum preventif dan represif.

Berkaitan dengan perlindungan preventif, yang ditujukan untuk mencegah terjadinya perlakuan yang tidak adil bagi notaris penerima protokol, maka dapat disampaikan di sini bahwa relatif belum ada pengaturannya saat ini. Karena itu perlu adanya pengaturan yang mencegah perlakuan yang tidak adil tersebut. Secara substansi, halhal yang perlu diatur akan diuraikan sebagai berikut.

Pertama, pengaturan tentang tanggung jawab ahli waris pemberi protokol. Hal ini diperlukan karena apabila notaris meninggal dunia, maka ahli warisnya wajib untuk melapor kepada MPD, kemudian menyerahkan protokol notaris tersebut kepada notaris lain yang ditunjuk oleh MPD. $^{20}$ Begitu juga dengan kewajiban seseorang di bidang perdata akan dilanjutkan kepada ahli waris, dibayarkan dengan harta yang ditinggalkan oleh pewaris.

Berkaitan dengan tanggung jawab perdata seorang notaris, apabila akibat dari perbuatan melawan hukum yang dilakukannya dalam pembuatan akta dapat merugikan orang lain, maka ia, sebagaimana diatur dalam Pasal 1365 Kitab Undang-undang Hukum Perdata (KUHPerdata), wajib membayar ganti kerugian. Apabila akta notaris dibatalkan oleh hakim setelah ia meninggal dunia, dan akibat dari pembatalan tersebut berakibat membawa kerugian bagi orang lain, maka hal ini menimbulkan pertanyaan apakah ahli warisnya ikut bertanggung jawab. Hal ini tentu dilihat terlebih dahulu jenis kesalahan dari notarisnya. Jika kesalahan ini berkaitan dengan keahlian atau sumber daya manusia yang bersifat subjektif, maka tidak dapat dibebankan kepada ahli warisnya. Akan tetapi, kewajiban notaris menyangkut harta, materi, maka dapat dibebankan kepada ahli waris. Teori Fautes de Services, yaitu teori yang menyatakan bahwa kerugian terhadap pihak ketiga dibebankan pada instansi dari pejabat yang bersangkutan. Menurut teori ini tanggung jawab

Febryka Nola, "Upaya Perlindungan Hukum secara Terpadu bagi Tenaga Kerja Indonesia (TKI)”, Negara Hukum, 7, 1 (2016), hlm. 40.

20 Lihat Pasal 63 ayat (2) UUJN Tahun 2004. 
dibebankan kepada jabatan. ${ }^{21}$ Kesalahan notaris yang merugikan orang lain akibat pembatalan akta oleh hakim setelah ia meninggal dunia, hanya merupakan tanggung jawab notaris secara pribadi bersifat subjektif, maka kerugian yang dialami pihak ketiga tidak dapat dibebankan kepada ahli waris.

Berbeda halnya dengan kewajiban notaris menjilid minuta akta yang harus dilakukan semasa hidupnya, akan tetapi tidak dilaksanakannya apakah dapat dibebankan kepada harta warisannya jika ada. Apabila notaris tidak melaksanakan penjilidan sampai pada saat terjadi penyerahan protokol notaris, maka hal tersebut akan menimbulkan kerugian pada penerima protokol. Pelaksanaan penjilidan minuta akta sebagaimana yang diwajibkan kepada notaris ${ }^{22}$ membutuhkan dana, dalam hal ini biaya penjilidan merupakan kewajiban notaris, maka ahli waris harus membiayai penjilidan dengan harta warisan notaris. Tanggung jawab ahli waris terhadap penjilidan perlu pengaturannya. Dengan demikian, obyek yang dapat diwariskan hanyalah berupa harta kekayaan dalam arti aktiva dan passiva, sedangkan perbuatan melawan hukum tidak masuk kategori warisan dalam hukum perdata. ${ }^{23}$ Karena itu, perbuatan melawan hukum oleh notaris yang bersifat subjektif tidak dapat dibebankan kepada ahli waris, sedangkan kewajiban menjilid akta termasuk kewajiban aktiva yang mesti dilakukannya semasa hidup.

Menurut hukum waris, berlaku suatu asas bahwa apabila seorang meninggal dunia, maka seketika itu juga segala hak dan kewajibannya beralih pada sekalian ahli warisnya. ${ }^{24} \mathrm{Hak}$ dan kewajiban yang dimaksud adalah hak dan kewajiban di bidang kekayaan, secara spesifik hak dan kewajiban yang dapat dinilai dengan uang. Di Indonesia terdapat tiga sistem hukum waris, yaitu: waris menurut

21 Anang Ade Irawan, A. Rachmad Budiono, dan Herlin Wijayanti, "Pertanggungjawaban Ahli Waris Notaris sebagai Pejabat Umum atas Akta Notaris yang Menimbulkan Kerugian Para Pihak”, Lentera Hukum, 5, 2 (2018), hlm. 351.

22 Pasal 16 ayat (1) huruf g UUJN Tahun 2014.

23 Irawan, dkk., "Pertanggungjawaban Ahli Waris Notaris", hlm. 354.

24 Ilyas, "Tanggung Jawab Ahli Waris terhadap Utang Pewaris Berdasarkan Hukum Islam”, Kanun Junal Ilmu Hukum, 13, 3 (2011), hlm. 131. 
hukum Islam, hukum adat, dan KUHPerdata. Hukum adat tidak mengenal akta notarial, maka tanggung jawab ahli waris di bidang kenotariatan tidak ada norma yang mengaturnya.

Dalam hukum waris Islam, sebagaimana Pasal 175 ayat (2) Kompilasi Hukum Islam (KHI), kewajiban ahli waris terhadap pewaris yang berkaitan dengan utang hanya sebatas harta yang ditinggalkan oleh pewaris. Artinya, apabila utang pewaris melebihi dari harta yang ditinggalkan, maka ahli waris tidak berkewajiban untuk menyelesaikan utang-utang pewaris. Bagi notaris yang beragama Islam tentu harus sadar pentingnya pelunasan kewajiban si pewaris melalui harta keakayaan yang ditinggalkan.

Berdasarkan KUHPerdata, seorang ahli waris dapat membuat pilihan terhadap warisan yang terbuka, yaitu: ahli waris dapat menerima atau juga dinamakan menerima penuh warisan tersebut; ahli waris dapat menolak warisan; dan ahli waris dapat menerima secara benificiar (menerima dengan syarat). ${ }^{25}$ Berkaitan dengan penerimaan warisan secara benificiar, dapat dilakukan secara tegas ataupun secara diam-diam. Apabila ahli waris mengambil atau menjual harta warisan berarti secara diam-diam ia bersedia menjadi ahli waris, maka berkewajiban membayar utang-utang si pewaris. ${ }^{26}$ Hukum waris perdata barat diatur dalam KUHPerdata hanya berlaku bagi notaris non muslim.

Berdasarkan ketiga sistem waris tersebut diketahui bahwa utang pewaris dapat beralih kepada ahli waris. Pelunasan utang pewaris merupakan kewajiban bagi ahli waris. Demikian pula dengan utang notaris terhadap protokol notaris yang harus dilakukan semasa hidupnya. Demi kepastian hukum, selayaknya ketentuan tentang biaya pelunasan utang notaris berkaitan protokol notaris dalam bidang teknis (finansial) memiliki aturan yang tegas agar ahli waris notaris pemberi protokol notaris bertanggung jawab atas pekerjaannya dan penerima protokol notaris tidak merasa dirugikan.

Kasus antara Muhammad Fadhol Indah Prasetyo melawan

25 Dermina Dalimunthe, "Penerimaan Warisan Harta secara Benifisier Perspektif Hukum Perdata”, Jurnal el-Qanuniy, 5, 1 (2019), hlm. 76.

26 Dalimunthe, "Penerimaan Warisan Harta secara Benifisier”, hlm. 84. 
Yusriansyah Makaramah memperlihatkan bagaimana peliknya hubungan antara notaris penerima protokol dan ahli waris dari notaris pemberi protokol. Dalam kasus ini, Fadhol sebagai penerima protokol menggugat ahli waris notaris Yusriansyah yang merupakan suami almarhumah Ni Nyoman Putri Yeni. Di antara keduanya terdapat perjanjian lisan yang pada pokoknya berisi kewajiban penerima protokol untuk menyelesaikan pekerjaan notaris Yeni yang belum selesai. Namun, setelah pekerjaan selesai dilakukan, tergugat tidak melakukan kewajibannya membayar biaya operasional yang telah dikeluarkan penggugat. Dalam persidangan tergugat tidak mengakui adanya perjanjian tersebut, dan hakim berpendapat permintaan pembayaran penggugat tidak berdasarkan alas hak yang sah, sehingga gugatan dinyatakan kabur (obscuur libele) dan ditolak. ${ }^{27}$

Pada kasus tersebut penerima protokol tidaklah terlindungi, karena isi gugatan dianggap kabur. ${ }^{28}$ Penerima protokol di sini tidak mampu mempertahankan hakmaterialnya dalam hukum formil, yaitu tidak bisa membuktikan telah adanya perjanjian secara lisan antara dirinya dan ahli waris pemberi protokol. Karena itu, agar penerima protokol terlindungi, maka perjanjian semacam itu haruslah dibuat tertulis, sehingga dihindari pihak-pihak yang aka mengikngkarinya.

Seharusnya pula, setelah seorang notaris meninggal dunia, maka pekerjaan notaris tersebut dilanjutkan oleh pejabat sementara notaris pengganti sampai jangka waktu 30 hari, dan setelahnya dilakukan penyerahan protokol oleh ahli waris kepada MPD. ${ }^{29}$ Penerima

27 Putusan Pengadilan Negeri Singaraja Nomor 30/Pdt.G/2018/PN.Sgr, $21 / 11 / 2018$, perkara perdata antara Muhammad Fadhol Indah Prasetyo lawan Yusriansyah Makaramah.

28 Pasal $8 \mathrm{Rv}$, menetapkan” bahwa penggugat harus merumuskan petitum dengan jelas”. Dan Pasal 94 Rv menyatakan” apabila Pasal 8 Rv tidak diikuti maka akibatnya gugatan batal, bukan tidak dapat diterima".

29 Pasal 1 angka 2 UUJN 2014: "Pejabat Sementara Notaris adalah seorang yang untuk sementara menjabat sebagai Notaris untuk menjalankan jabatan dari Notaris yang meninggal dunia”. Pasal 63 ayat (1): Penyerahan protokol sebagaimana dimaksud dalam Pasal 62 dilakukan paling lama 30 hari dengan pembuatan berita acara penyerahan protokol notaris yang ditandatangani oleh yang menyerahkan dan yang menerima protokol notaris; ayat (2): "Dalam hal terjadi sebagaimana dimaksud dalam Pasal 62 huruf a, penyerahan protokol notaris dilakukan oleh ahli waris 
protokol hanya sebagai penyimpan akta dari notaris pemberi protokol, bukan membuatkan akta untuk melanjutkan pekerjaan notaris pemberi protokol.

Kedua, pengaturan batasan tanggung jawab penerima protokol. Berdasarkan Pasal 62 dan Pasal 63 UUJN Tahun 2004, apabila notaris meninggal dunia, telah berakhir masa jabatannya, minta sendiri, tidak mampu secara rohani dan/atau jasmani untuk melaksanakan tugas jabatan sebagai notaris secara terus-menerus lebih dari tiga tahun, diangkat menjadi pejabat negara, pindah wilayah jabatan, diberhentikan sementara, atau diberhentikan dengan tidak hormat, maka protokol notarisnya diserahkan kepada penerima protokol notaris yang ditunjuk oleh Majelis Pengawas Daerah.

Ditinjau dari lama waktu alasan penyerahan protokol ini dapat dikelompokkan ke dalam dua kelompok: jangka pendek dan jangka panjang. Penyerahan protokol jangka pendek adalah penyerahan protokol karena alasan cuti atau sakit, sehingga ia tidak bisa menjalankan kewajibannya sebagai notaris. Berdasarkan ketentuan Pasal 32 UUJN Tahun 2004, notaris yang menjalankan cuti wajib menyerahkan protokol notaris kepada notaris pengganti. Setelah cutinya berakhir, maka notaris pengganti menyerahkan kembali protokol notaris kepada notaris semula. Penyerahan protokolnya dilakukan kepada notaris pengganti sementara, yaitu seorang sarjana hukum yang telah bekerja pada notaris minimal dua tahun. ${ }^{30}$ Pada umumya ia telah bekerja pada notaris yang cuti, sehingga protokol notaris tidak keluar dari gedung notaris yang cuti.

Sedangkan penyerahan protokol jangka panjang adalah penyerahan protokol oleh notaris yang diberhentikan jabatannya sebagaimana ketentuan Pasal 9 dan Pasal 62 UUJN Tahun 2014. Pada ketentuan tersebut, alasannya adalah karena dalam proses pailit atau penundaan kewajiban pembayaran utang; berada di bawah pengampuan; melakukan perbuatan tercela; melakukan pelanggaran terhadap kewajiban dan larangan jabatan serta kode etik notaris; sedang menjalani masa penahanan; mencapai usia pensiun,

notaris kepada notaris lain yang ditunjuk oleh Majelis Pengawas Daerah. 30 Pasal 33 UUJN Tahun 2004. 
meninggal dunia, pindah domisili; alih profesi. Semua protokol notaris harus diserahkan kepada notaris lain berdasarkan notaris yang ditunjuk oleh Majelis Pengawas Daerah, atau kepada notaris lain yang ditunjuk oleh pemberi protokol dan disetujui oleh Majelis Pengawas Daerah, melalui prosedur yang ditentukan oleh peraturan perundang-undangan. Lama penyimpanan protokol notaris tersebut oleh penerima protokol adalah 25 tahun. Sebagai penerima protokol, ia wajib menyimpan, sehingga protokol notaris menjadi aman. Apabila dalam penyimpanan tersebut terjadi kerusakan atau hilang yang disebabkan oleh kelalaian atau kesalahan penerima protokol, maka ia harus bertanggung jawab. Tanggung jawab ini dapat dikecualikan apabila kerusakan atau kehilangan tersebut dikarenakan peristiwa overmacht, seperti banjir, kebakaran, protokol hancur secara alami karena dimakan rayap. Akibat dari peristiwa overmacht, notaris penerima protokol tidak dapat dituntut.

Agar penyimpanan tersebut aman dan penting dalam pembuktian perdata, maka protokol notaris terutama minuta akta dapat disimpan dalam bentuk mikroflim yang tidak bisa diubah atau diedit oleh siapapun atau pelaku informatika teknologi elektronik. Salah satu cara pengamanan akta dalam softcopy atau mikroflim adalah membuat QR (quick response) Code pada akta tersebut. QR Code atau respons cepat adalah suatu jenis kode matriks atau barkode dalam dua dimensi dengan fungsionalitas utama dapat dengan mudah dibaca oleh pemindai $\mathrm{QR}$, yang sesuai dengan tujuannya adalah untuk menyampaikan informasi dengan cepat dan mendapatkan respons yang cepat pula. ${ }^{31}$

Pada Pasal 63 UUJN Tahun 2014 ditetapkan bahwa setelah 25 tahun dokumen yang disimpan oleh penerima protokol akan diserahkan kembali kepada Majelis Pengawas Daerah setempat. Berhubung Majelis Pengawas Daerah setempat tidak mempunyai gedung atau gudang penyimpan protokol akta, maka sebaiknya penyimpanan dapat dilakukan melalui media elektronik, seperti harddisk, flashdisk, atau memory card. Agar media ini tidak hilang dan

31 Asep Id Hadiana, "Pemanfaatan Teknologi QR Code untuk Verifikasi Akta Notaris (PPAT)”, MIND Journal, 1, 1 (2016), hlm. 42. 
tidak mudah diedit atau diubah isinya maka diperlukan ahli yang bersifat teknisi. Penyimpanan protokol notaris tidak kehilangan fungsi pembuktian sebagaimana akta otentik yang aslinya, sepanjang akta dalam bentuk elektronik dibuat dalam bentuk scan dari yang asli, kemudian disahkan kan oleh pejabat yang berwenang, yaitu Ketua Pengawas Majelis Daerah yang sah pada saat dibuatnya pengalihan akta kedalam bentuk soft copy. Menurut Putusan Mahkamah Agung Nomor nomor 112K/Pdt/1996, 7/9/1998, "fotokopi sebagai alat bukti yang sah yang disertai atau dicocokkan dengan yang aslinya, adalah alat bukti yang sah" ${ }^{32}$ Hasil fotokopi dapat ditafsirkan sama dengan teknik pindai (scan). Hasil pindai yang telah disahkan dapat disimpan dalam kartu memori (memory card), yang kemudian disimpan oleh Majelis Pengawas Daerah.

Dilihat dari segi kemanfaatannya, penyimpanan protokol dalam bentuk elektronik sesungguhnya sangat efisien, sepanjang didukung oleh peraturan tertulis. ${ }^{33}$ Peraturan perundang-undang secara tertulis bertujuan agar adanya kepastian hukum, dalam penyimpanan akta, dan akta tersimpan aman dan terhindar dari perbuat orang yang ingin meedit atau merubah suatu dokumen.

Akta yang disimpan secara elektronik ${ }^{34}$ tidak kehilangan fungsinya sebagaimana aslinya sepanjang memenuhi: kekuatan pembuk-

32 Sebaliknya, dalam hal fotokopi tidak disertai atau tidak dapat dicocokkan dengan aslinya atau tanpa didukung oleh keterangan saksi dan/atau bukti lainnya, maka bukan termasuk alat bukti yang sah. Devina Puspita Sari, "Kekuatan Pembuktian Fotokopi Surat yang Tidak Dapat Dicocokkan dengan Aslinya dalam Perkara Perdata", Undang: Jurnal Hukum, 2, 2 (2019), hlm. 328.

33 Mohamat Riza Kuswanto dan Hari Purwadi, "Urgensi Penyimpanan Protokol Notaris dalam Bentuk Elektronik dan Kepastian Hukumnya di Indonesia", Jurnal Repertorium, 4, 2 (2017), hlm. 66.

34 Akta yang disimpan secara elektronik tentu berbeda dengan akta dalam bentuk elektronik sebagai hasil praktik cyber notary. Tentang akta elektronik, maka ia tidak memiliki kekuatan pembuktian yang sempurna layaknya akta otentik. Akta elektronik sejauh ini hanya dianggap sebagai akta di bawah tangan yang disamakan dengan dokumen, surat dan sertifikat elektronik. Andes Willy Wijaya, "Konsep Dasar Cyber Notary: Keabsahan Akta dalam Bentuk Elektronik", https://vivajusticia.law.ugm.ac.id/2018/11/29/ konsep-dasar-cyber-notary-keabsahan-akta-dalam-bentuk-elektronik/, 29/11/2018, diakses 17/4/2021. 
tian formal, kekuatan pembuktian materil, dan kekuatan pembuktian lahir. Kekuatan pembuktian formal mengandung makna apa yang tertulis dalam akta itulah yang benar, seperti kebenaran tanggal, identitas para pihak, tanda tangan. Kekuatan pembuktian materiil mengandung arti para pihak benar telah melakukan perbuatan hukum sebagaimana tercantum dalam akta. Sedangkan kekuatan pembuktian lahir maksudnya kemampuan dari akta itu sendiri sebagai akta yang dibuat oleh pejabat yang berwenang, sehingga akta itu alat bukti yang sempurna. ${ }^{35}$ Meskipun minuta akta dibuat dan disimpan dalam bentuk elektronik, ia tetap mempunyai kekuatan pembuktian yang sama dengan akta dalam bentuk hardcopy.

Tanggung jawab penerima protokol hanya sebatas penyimpanan dokumen selama 25 tahun. Penerima protokol bertanggung jawab atas protokol yang hilang atau rusak setelah diterimanya. Pada saat protokol proses serah terima akta, penerima akta harus teliti memeriksa protokol akta, dan jika ada dokumen yang rusak harus dicatat dalam berita acara penyerahan.

Tanggung jawab lahir karena adanya unsur kesalahan atau kelalaian menurut Pasal 1365 dan 1366 KUHPerdata menetapkan, siapa yang melakukan perbuatan sengaja atau lalai ataupun tidak hatihati sehingga merugikan pihak lain, maka ia harus bertanggung jawab atas kerugian tersebut. Tanggung jawab keabsahan dan kebenaran akta akibat kesalahan atau kelalaian atau ketidak hati-hatian notaris pemberi protokol bukanlah tanggung jawab penerima protokol. Begitu juga kesalahan atau kelalaian para pihak yang membuat membuat perjanjian dalam akta notaris sehingga merugikan salah satu pihak, bukanlah tanggung jawab notaris, melainkan tanggung jawab para pihak yang mengikat perjanjian. Oleh karena itu, terhadap setiap kegiatan dan aktenya, notaris dapat dikatakan bertanggung jawab penuh sehingga mutu dokumennya dikategorikan sebagai akta autentik dan mempunyai kekuatan eksekutorial. ${ }^{36}$

35 Dedy Pramono, "Kekuatan Pembuktian Akta yang Dibuat Notaris selaku Pejabat Umum Menurut Hukum Acara Perdata di Indonesia”, Lex Jurnalica, 12, 3 (2015), hlm. 254.

36 Kuswanto dan Purwadi, "Urgensi Penyimpanan Protokol Notaris", hlm. 
Begitu pula pendapat Sri Peni Nughrohowati, yang mengatakan bahwa "notaris dapat dituntut bertanggungjawab secara perdata apabila para pihak melakukan pengingkaran: hari, tanggal, bulan, tahun menghadap; waktu, pukul menghadap; tanda-tangan yang tercantum dalam minuta; merasa tidak pernah menghadap; akta tidak ditandatangani di depan notaris; akta tidak dibacakan; dan alasan lain berdasarkan formalitas akta" ${ }^{37}$ Sesuai dengan prinsip facta sunt servanda, bahwa perjanjian itu mengikat para pihak yang membuatnya, maka kebenaran dan keabsahan suatu akta adalah tanggung jawab dari para pihak yang membuatnya. Maka oleh sebab itu hakim tidak dapat menjatuhkan sanksi uang paksa ataupun denda kepada penerima protokol akibat dibatalkannya suatu akta yang diterima. Pengaturan tanggung jawab penerima protokol seharusnya diatur dalam UUJN.

Pada perkara pidana, notaris pemberi ataupun notaris penerima protokol tidak dapat dituntut atas perbuatan pidana para pihak dalam akta notaris. Ia hanya bisa menjadi saksi terhadap tindak pidana yang disangkakan pada seseorang yang dilakukan atau terjadi di hadapan notaris. Petunjuk Mahkamah Agung Nomor MA/Pemb/3425/86, 12/4/1986 yang dibacakan oleh Sofyan Sitompul menyebutkan, berdasarkan Pasal 170 Kitab Undang-undang Hukum Acara Pidana (KUHAP) bahwa hak ingkar notaris dapat dilepaskan demi kepentingan umum. ${ }^{38}$ Notaris penerima protokol sesungguhnya tidak pernah tahu tentang kehadiran para pihak di depan notaris pemberi protokol. Ia memiliki hak ingkar untuk memperlihatkan minuta akta di depan persidangan, karena ia juga berkewajiban merahasiakan akta.

Ketiga, pengaturan batasan waktu penyimpanan protokol bagi penerima protokol. Berdasarkan ketentuan Pasal 1 angka (13) UUJN

64.

37 Kunni Afifah, "Tanggung Jawab dan Perlindungan Hukum bagi Notaris secara Perdata terhadap Akta yang Dibuatnya”, Lex Renaissance, 2, 1 (2017), hlm. 155 .

38 Agus Sahbani, "Hak Ingkar Bukan untuk Melindungi Notaris”, https:// www.hukumonline.com/berita/baca/lt52948b592619f/hak-ingkar-bukanuntuk-lindungi-notaris/, 26/11/2013, diakses 18/7/2019. 
Tahun 2014, protokol notaris adalah kumpulan dokumen yang merupakan arsip negara yang harus disimpan dan dipelihara oleh notaris. Penyimpanan protokol notaris dilakukan oleh notaris. Akan tetapi apabila ia tidak dapat melakukan kewajibannya sebagai notaris, maka ia harus menyerahkannya kepada notaris lain yang ditunjuk oleh Majelis Pengawas Daerah setempat. Dalam Penjelasan Pasal 62 UU Nomor 30 Tahun 2004 disebutkan bahwa protokol notaris terdiri atas: minuta akta; buku daftar akta atau repertorium; buku daftar akta di bawah tangan yang penandatanganannya dilakukan di hadapan notaris atau akta di bawah tangan yang didaftar; buku daftar nama penghadap atau klapper; buku daftar protes; buku daftar wasiat; dan buku daftar lain yang harus disimpan oleh notaris berdasarkan ketentuan peraturan perundang-undangan.

Keempat, penyimpanan protokol notaris dalam bentuk media elektronik. Lama penyimpanan protokol notaris oleh penerima protokol menurut Pasal 63 ayat (5) UUJN Tahun 2004 adalah 25 tahun. Setelah habis jangka waktu tersebut, protokol notaris diserahkan kepada Majelis Pengawas Daerah setempat, sementara Majelis Notaris Pengawas Daerah tidak punya gudang atau gedung untuk menyimpannya. Problematika tersebut dapat diatasi sewaktu pembuatan akta, ataupun setelah pembuatan akta, harus ada norma hukum yang mengatur tentang penyimpanan protokol dalam bentuk media elektronik.

Media penyimpanan secara elektronik (komputer) bisa dibedakan ke dalama tiga macam: penyimpanan magnetik (magnetic disc), penyimpanan optikal (optical disk), dan penyimpanan awan (cloud storage). Media penyimpanan magnetik sendiri terdiri dari: disket, harddisk, flashdisk, memory card, dan zip drive. Sedangkan penyimpanan optikal terdiri dari CD (compact disk), CD-ROM, WORM, CD-RW (compact disk rewiteable), DVD (digital video disc), penyimpanan awan (cloud storage). Sedangkan media penyimpanan awan memanfaatkan adanya server virtual yang berbasis internet. ${ }^{39}$ Media yang dapat dipakai tersebut haruslah selektif sehingga data yang tersimpan aman

39 Nur Fahri, "Digital Storage”, https://nurfahri.web.ugm.ac.id/category/ pengantar-teknologi-informasi/page/6/, diakses 17/4/2021. 
dari berbagai bahaya. Sebagaimana disampaikan Olegovna Agnessa Inshakova, dkk., untuk membantu kegiatan notaris diperlukan pengembangan dan pengaturan informasi modern dan teknologi telekomunikasi. ${ }^{40}$

Penyimpanan dokumen dalam bentuk media elektronik sangat membantu semua orang untuk mengantisipasi ruangan yang terbatas, bahaya kebakaran, banjir, rayap, boros kertas, kertas rusak karena udara yang lembab dan bencana alam lainnya. Pengalihan dokumen dari bentuk tertulis menuju media elektronik sudah dikenal dan dilegalisasi oleh Undang-undang Nomor 20 Tahun 1997 tentang Dokumen Perusahaan, Undang-undang Nomor 43 Tahun 2009 tentang Kearsipan, Undang-undang Nomor 11 Tahun 2008 tentang Informasi dan Transaksi Elektronik, Undang-undang Nomor 19 Tahun 2016 tentang Perubahan Undang-undang Nomor 11 Tahun 2008 tentang Informasi dan Transaksi Elektronik.

Penyimpan minuta akta notaris yang dibuat secara tertulis secara sah, dipindai atau difoto, kemudian disimpan dalam media elektronik dalam sebuah file suatu harddisk sehingga dokumen tersimpan dalam bentuk mikrofilm, dan diberi QR Code. Akan lebih aman lagi apabila file minuta akta dibagi (share) ke surel khusus, dengan tujuan agar terhindar dari virus atau kerusakan komputer, surel khusus tersebut disimpan pada sekretariat Majelis Pengawas Daerah. Meskipun data tersimpan dalam bentuk soft copy, maka hard copy juga tetap tersimpan, hal jika kondisi tempat penyimpanan protokol memungkinkan di ruang penyimpanan protokol. Selain minuta akta, juga buku-buku yang dipergunakan notaris juga disimpan sama seperti halnya minuta akta.

Dokumen dalam bentuk mikrofilm dapat dijadikan sebagai alat bukti, sebagaimana putusan Mahkamah Agung Nomor 272/ Pdt.G/2015/DA.K5 tanggal 6 Januari 2016, bahwa "fax, microfilm atau microfiche dapat dianggap sebagai alat bukti tertulis yang dapat

40 Olegovna Agnessa Inshakova, dkk., "Modern Communication Technologies in Notification of Notarial Actions in Russia”, Journal of Advanced Research in Law and Economics, 8, 7 (2017), 2144-51. 
dijamin keautentikanya". ${ }^{41}$ Dokumen fax, microfilm atau microfiche yang dapat dijadikan alat bukti sepanjang isi surat menurut teknologi tidak dapat diubah atau diedit. Dalam pembuktian di pengadilan, diperlukan saksi ahli yang dapat membuktikan keautentikan minuta akta.

Penyimpanan akta dalam bentuk soft copy ataupun hard copy oleh penerima protokol dapat berlangsung selama 25 tahun. Oleh sebab itu dalam proses penyerahan protokol notaris kepada notaris penerima terlebih dahulu dilakukan pelaporan dari notaris yang akan mengakhiri masa jabatannya, atau oleh ahli waris jika pemberi protokol telah meninggal dunia secara langsung atau melalui media elektronik kepada Majelis Pengawas Daerah; Majelis Pengawas Daerah menunjuk notaris penerima protokol; kesediaan dari notaris penerima protokol; proses serah terima dari pemberi protokol kepada notaris penerima protokol terdahulu, sebelum penandatanganan berita acara terlebih penerima mengecek kondisi protokol, baik dari segi kuantitas maupun kualitas akta yang akan diterimanya. ${ }^{42}$ Sewaktu pengecekan kondisi protokol, pihak penerima berwenang meminta pemenuhan kewajiban notaris penerima yang belum dilakukan, seperti meminta biaya penjilidan minuta akta. Apabila ada jumlah akta sesuai antara laporan pemberi akta, maka kekurangan atau ketiadaan akta harus ditulis dalam berita acara, tujuannya adalah untuk melindungi penerima protokol jika terjadi sengketa terkait minuta akta yang tidak pernah diterimanya. Penandatangan berita acara penyerahan protokol notaris kepada penerima protokol yang baru dilakukan dan ditandatangani para pihak di hadapan Majelis Pengawas Daerah.

Kelima, hak ingkar penerima protokol notaris. Hak ingkar adalah hak menolak memberikan keterangan tentang akta yang dibuat notaris di depan persidangan. Landasan yuridis hak ingkar

41 Efa Laela Fakhriah, Bukti Elektronik dalam Sistem Pembuktian Perdata (Bandung: Refika Aditama, 2017), hlm. 47.

42 Yofi Permana R., "Pengaturan Penyerahan Protokol Notaris yang Telah Meninggal Dunia dan Prakteknya di Sumatera Barat”, Jurnal Cendekia Hukum, 5, 1 (2019), hlm. 12. 
terkandung pada Pasal 16 ayat (1e) UUJN Tahun 2004, yang mana hak ini bermaksud adalah suatu kewajiban untuk merahasiakan akta. Dikatakan "hak" karena menolak datang ke pengadilan, dan dikatakan "kewajiban" karena keharusan merahasiakan isi akta.

Melalui hak ingkar notaris bahwa ia tidak dapat membuka protokol akta dalam persidangan, maka notaris penerima protokol hanya bisa berfungsi sebagai saksi tentang adanya dokumen yang disimpannya berasal dari notaris pemberi protokol. Sebagai saksi, ia akan dilindungi oleh Undang-undang Nomor 31 Tahun 2014 tentang Perubahan atas Undang-undang Nomor 13 Tahun 2006 tentang Perlindungan Saksi dan Korban.

Sebagai pengecualian dari hak ingkar, pada proses peradilan, penyidikan, penuntut umum, hakim harus minta persetujuan dari Majelis Kehormatan Notaris, untuk dapat mengambil fotokopi minuta akta dan atau dokumen lain yang melekat dengan minuta akta membutuhkan akta notaris, dan dapat juga memangil notaris sebagai saksi dipersidangan. Persetujuan dari Majelis Kehormatan Notaris sebagaimana diatur pada Peraturan Menteri Hukum dan HAM Nomor 7 tahun 2016 tentang Majelis Kehormatan Notaris, adalah bertujuan untuk melindungi akta notaris yang bersifat rahasia, karena notaris adalah pejabat yang membuat akta dengan kekuatan pembuktian yang sempurna.

Selanjutnya perlu pula ditelaah perlindungan hukum penerima protokol secara represif. Perlindungan hukum secara represif atau kuratif adalah perlindungan yang bertujuan untuk melindungi notaris penerima protokol setelah terjadinya sengketa, agar tidak diperlakukan semena-semena oleh penegak hukum atau pihak lainnya. Adapun bentuk perlindung represif dapat diuraikan sebagai berikut. Pertama, Izin Majelis Kehormatan Notaris (MKN) untuk hadir di persidangan. Penerima protokol notaris harus terlebih dahulu mendapat izin dari MKN untuk hadir di persidangan. Setiap notaris penerima protokol apabila dipanggil ke pengadilan, maka ia harus terlebih dahulu mendapat izin dari MKN.

Kewenangan yang diberikan Pasal 66 UUJN Tahun 2014 memberi persetujuan kepada penegak hukum dalam proses penyidikan, 
penuntutan dan persidangan, untuk mengambil fotokopi protokol notaris termasuk fotokopi minuta akta. Tentu fotokopi tersebut harus dilegalisasi terlebih dahulu oleh penerima protokol, sehingga ada kecocokan dengan aslinya. Hal demikian diperbolehkan oleh Pasal 15 UUJN Tahun 2014.

Menurut Pasal 66 ayat (3) UUJN Tahun 2014 menetapkan dalam rentang waktu 30 hari MKN dapat menyetujui atau menolak permintaan penegak hukum setelah diadakan rapat dengan para anggota MKN Wilayah. MKN berwenang memberikan izin atau menolak untuk memperlihatkan salinan minuta akta di depan hakim, dan penegak hukum tidak diperkenankan mengambil minuta akta dan/atau surat-surat asli yang dilekatkan pada minuta akta atau protokol notaris dalam penyimpanan dokumen notaris. Perbuatan persetujuan dari MKN merupakan bentuk perlindungan terhadap akta notaris. Begitu juga bagi penerima protokol notaris yang menyimpan protokol dari notaris yang menyerahkan kepadanya, juga mendapatkan perlindungan. Setelah dipanggil dan menghadap pada rapat MKN Wilayah, ia bisa membela diri bahwa sesuatu yang menyangkut keabsahan akta bukanlah kesalahan pada dirinya, sehingga tidak bisa dimintakan pertanggung jawaban, kecuali terkait kerusakan akta karena kelalaiannya dalam menyimpannya. Notaris penerima protokol harus bisa membuktikan bahwa protokol yang diterimanya begitulah adanya, ditunjukkan pula dengan berita acara serah terima di hadapan MPD.

Putusan Pengadilan Tinggi Bandung Nomor 485/PDT/2018/ PT.BDG merupakan contoh notaris penerima protokol dilindungi hukum. Sebagai turut tergugat, notaris penerima protokol dalam putusan ini dinyatakan tidak ada alasan untuk telah wanprestasi atau melakukan perbuatan melawan hukum, meskipun akta jual beli yang disimpannya dinyatakan batal demi hukum. ${ }^{43}$ Dari putusan ini diketahui bahwa penerima protokol bukanlah sebagai pihak yang dapat dimintai tanggung jawab terkait keabsahan suatu akta,

43 Putusan Pengadilan Tinggi Bandung Nomor 485/PDT/2018/PT.BDG, 28/11/2018, perkara perdata antara A. Kosasih melawan Sudjono Barak Rimba, dkk. 
karena ia hanya sebagai pihak yang menyimpan dokumen. Penerima protokol tidak bisa diberikan sanksi hukum apabila unsur-unsur perbuatan melawan hukum tidak terpenuhi. Kalaupun dihadirkan dalam suatu persidangan di pengadilan, notaris penerima protokol hanyalah berstatus sebagai saksi, sehingga menjadi pihak yang dilindungi melalui Undang-undang Perlindungan saksi.

Menurut Pasal 1 Undang-undang Nomor 14 Tahun 2006 tentang Perlindungan Saksi dan Korban, saksi adalah orang yang memberikan kesaksian tentang apa yang dilihat, didengar, atau dialaminya dalam proses peradilan pidana. Sedangkan saksi dalam hukum acara perdata yaitu orang dapat memberikan keterangan tentang apa yang dilihat, didengar, dan dialaminya dalam perkara perdata. Terkait dengan protokol yang diterimanya, notaris penerima protokol tidaklah melihat dan mengetahui proses pembuatan akta yang terjadi pada waktu yang lampau. Ia hanya melihat dan mengetahui apa yang tercantum pada minuta akta dan protokol yang diterimanya. Karena itu, penerima protokol hanya bisa menyampaikan kepada hakim di pengadilan apa yang diterimanya sesuai berita acara penyerahan protokol notaris yang ada pada MPD, yaitu tentang bagaimana kondisi protokol yang diterima, berapa jumlah minuta akta, penjilidan minuta akta, buku admintrasi, dan sebagainya.

Kedua, notaris penerima protokol tidak bertanggung jawab atas keabsahan minuta akta. Penerima protokol hanya pihak penyimpan terkait kasus protokol notaris, sehingga tidak dapat dikenai sanksi atas keabsahan akta yang diterimanya. Keabsahan akta yang diterima notaris penerima protokol di luar pengetahuannya, karena akta dibuat sebelum diterimanya. Keabsahan akta notaris tetap berada di bawah tanggung jawab notaris pembuat akta, meskipun protokol telah diserahkan kepada penerima protokol. ${ }^{44}$ Apabila terjadi perusakan protokol yang disimpannya, maka penerima protokol bisa membuktikan, siapa yang merusak akta serta peristiwa apa yang

44 Pasal 65 UUJN Tahun 2004: "Notaris, Notaris Pengganti, Notaris Pengganti Khusus, dan Pejabat Sementara Notaris bertanggung jawab atas setiap akta yang dibuatnya meskipun Protokol Notaris diserahkan atau dipindahkan kepada penyimpan Protokol Notaris". 
menyebabkan terjadinya kerusakan protokol. Jika kerusakan terjadi disebabkan oleh kesalahan atau kelalaiannya, maka ia harus bertanggung jawab sesuai peraturan yang berlaku.

\section{Batasan Perlindungan Hukum bagi Notaris Penerima Protokol}

Sebagaimana uraian terdahulu, perlindungan hukum merupakan hal penting bagi siapa pun dalam menjalankan aktivitasnya, termasuk notaris penerima protokol dalam hal menyimpan protokol yang diberikan atau dipindahkan kepadanya. Adanya jaminan perlindungan hukum akan mendorong notaris penerima protokol menjadi aman dan nyaman dalam melaksanakan tugas kewajibannya. Namun demikian, perlindungan hukum juga mesti proporsional atau seimbang, dalam artian perlu pula ada batasan-batasannya. Batasan dalam perlindungan hukum, yang berarti notaris tidak dilindungi hukum sehingga perlu dan harus pula dimintai pertanggungjawabannya, dimaksudkan untuk menjaga keseimbangan akan perlindungan hukum yang telah diberikan. Dengan begitu, notaris akan menjalankan tugas dan kewajibannya secara profesional dan bertanggung jawab.

Dalam situasi dan kondisi notaris harus bertanggung jawab terkait protokol yang disimpannya, maka hal ini sesungguhnya adalah batasan dari perlindungan hukum yang diberikan kepadanya. Tanggung jawab sendiri muncul dari adanya aturan hukum yang memberikan kewajiban kepada subyek hukum dengan ancaman sanksi apabila tidak dilaksanakan. Tanggung jawab semacam ini dapat disebut sebagai tanggung jawab hukum karena muncul dari perintah aturan hukum dan juga sanksi yang telah ditetapkan. ${ }^{45}$

Tanggung jawab sebagai batasan dari perlindungan hukum ini bisa muncul karena telah terjadi perbuatan melawan hukum terkait kewajiban yang harus dipenuhi oleh subyek hukum. Dalam ilmu

45 Vina Akfa Dyani, "Pertanggungjawaban Hukum dan Perlindungan Hukum bagi Notaris dalam Membuat Paryy Acte”, Lex Renaissance, 2, 1 (2017), hlm. 166. 
hukum dikenal tiga kategori perbuatan melawan hukum, yang ini nanti menimbulkan tiga model pertanggungjawaban. Tiga kategori perbuatan melawan hukum ini ialah: perbuatan melawan hukum karena kesengajaan, perbuatan melawan hukum tanpa kesalahan (tanpa unsur kesengajaan ataupun kelalaian), dan perbuatan melawan hukum karena kelalaian. Sedangkan tiga model pertanggungjawaban hukumnya adalah: tanggung jawab dengan unsur kesalahan sebagaimana Pasal 1365 KUHPerdata, tanggung jawab dengan unsur kesalahan khususnya kelalaian sebagaimana Pasal 1366 KUHPerdata, dan tanggung jawab mutlak sebagaimana Pasal 1367 KUHPerdata. ${ }^{46}$

Batasan perlindungan hukum bagi notaris penerima protokol terkait dengan tanggung jawab pribadi, karena telah melakukan perbuatan melawan hukum ataupun wanprestasi dalam menyimpan protokol. Sebagaimana bahasan sebelumnya, notaris penerima protokol mempunyai kewajiban untuk menyimpan protokol yang diberikan atau dipindahkan kepadanya. Perbuatan melawan hukum bisa saja terjadi, jika penerima protokol tidak menyimpan protokol notaris secara aman, tidak mau memberikan kesaksian jika dibutuhkan oleh yang berwajib meskipun telah mendapat persetujuan dari MKN, tidak menjaga kerahasiaan akta. Notaris juga berkewajiban, sebagaimana ketentuan pasal 64 ayat (2) UUJN Tahun 2004, membuat grosse akta, salinan akta, atau kutipan akta, serta tidak boleh, sebagaimana ketentuan Pasal 48 UUJN Tahun 2014, mengganti, menambah, mencoret, menyisipkan, menghapus, dan menulis tindih.

Apabila terjadi kerusakan pada protokol yang disimpannya, penerima protokol bisa membuktikan siapa yang merusak akta atau peristiwa apa yang menyebabkannya. Jika kerusakan protokol notaris terjadi atas kesalahan atau kelalaiannya, maka ia harus bertanggung jawab. Apabila penerima protokol melakukan hal tersebut, maka ia tidak dilindungi, karena telah melakukan perbuatan melawan hukum.

Minuta akta sebagai salah satu dari protokol notaris memerlukan penyimpanan khusus, karena adanya kewajiban untuk merahasiakan

46 Munir Fuady, Perbuatan Melawan Hukum (Bandung: Citra Aditya Bakti, 2002), hlm. 3. 
akta. Minuta akta tersusun dalam lemari khusus dan rapi berdasarkan tahun pembuatan, dengan tujuan agar mudah sewaktu-waktu mengambilnya untuk pembuktian. Minuta akta diterima dapat dipisahkan dari minuta akta buatan sendiri. Penyimpanan protokol yang aman dapat diartikan dengan kelengkapan dokumen, tidak rusak, oleh karena itu harus disediakan tempat khusus dalam ruangan yang terkunci, dan kunci harus dipegang sendiri oleh penerima protokol.

Apabila penerima protokol tidak menyimpannya secara baik, lalu terjadi kehilangan atau kerusakan dokumen semenjak berada dalam kekuasaannya, maka hal ini merupakan kesalahan atau kelalaiannya. Dalam keadaan semacam itu, notaris penerima protokol harus bertanggung jawab secara pribadi. Tanggung jawab pribadi terjadi karena seseorang telah melakukan perbuatan melanggar hukum.

Sanksi hukum kepada penerima protokol dalam UUJN (2044 dan 2014) tidak ada pengaturannya. Dalam Pasal 85 UUJN Tahun 2004, sanksi hukum terdiri dari: teguran lisan; teguran tertulis; pemberhentian sementara; pemberhentian dengan hormat; atau pemberhentian dengan tidak hormat. Semua jenis sanksi tersebut merupakan sanski administratif. Apabila notaris penerima protokol sengaja melakukan perbuatan pidana seperti menghilangkan minuta akta sebagai alat bukti, memberikan keterangan palsu, tentu hal ini akan merujuk pula pada ketentuan dalam Kitab Undang-undang Hukum Pidana (KUHP).

Perbuatan penjilidan minuta akta pada dasarnya termasuk sebagai perbuatan administrasi yang wajib dilakukan oleh setiap notaris. ${ }^{47}$ Namun karena notaris pemberi protokol belum selesai melakukannya, dan ia meninggal dunia, maka perbuatan penjilidan dapat saja dilakukan oleh notaris pengganti atau pejabat notaris sementara. ${ }^{48}$ Demikian pula, wanprestasi bisa saja terjadi, jika antara penerima protokol dan ahli waris pemberi protokol telah membuat perjanjian tentang kegiatan penjilidan minuta akta yang belum terlaksana oleh pemberi protokol yang meninggal dunia, dan penerima protokol tidak melaksanakannya.

47 Pasal 16 ayat (1g) UUJN Tahun 2014.

48 Pasal 35 ayat (3) UUJN Tahun 2004. 


\section{E. Kesimpulan}

Perlindungan hukum terhadap notaris penerima protokol sangatlah penting. Selain agar notaris penerima protokol menjadi aman dan nyaman dalam melaksanakan tugas dan kewajibannya yaitu menyimpan, memelihara, dan menjaga protokol yang diberikan atau dipindahkan kepadanya, perlindungan hukum juga diperlukan karena merupakan pemenuhan hak konstitusional warga negara serta agar terhindari ketidakadilan dan ketidakpastian hukum. Mengingat pengaturan perlindungan hukum terhadap notaris penerima protokol belum ada, maka bentuk perlindungan yang perlu diupayakan antara lain adalah: pembatasan tanggung jawab penerima protokol; pembebanan sebagian tanggung jawab pada ahli waris pemberi protokol; pembatasan waktu penyimpanan protokol; penyimpanan protokol dalam media elektronik; serta hak ingkar penerima protokol. Secara represif, perlindungan hukum juga perlu diberikan berupa izin dari Majelis Kehormatan Notaris jika ada pemanggilan ke pengadilan; kehadiran di persidangan terbatas sebagai saksi; serta ketiadaan sanksi terkait pembatalan akta oleh hakim. Perlindungan hukum terhadap penerima protokol dibatasi pada keharusannya menyimpan, memelihara, dan menjaga protokol secara patut dan bertanggung jawab. Apabila kewajibannya ini tidak dipenuhi, maka ia bisa dimintai pertanggungjawaban.

\section{Daftar Pustaka}

\section{Artikel, Buku, dan Laporan}

Afifah, Kunni. "Tanggung Jawab dan Perlindungan Hukum bagi Notaris secara Perdata terhadap Akta yang Dibuatnya”. Lex Renaissance: 2, 1 (2017): 147-61. DOI: 10.20885/JLR.vol2.iss1. art10.

Dalimunthe, Dermina. "Penerimaan Warisan Harta secara Benifisier Perspektif Hukum Perdata”. Jurnal el-Qanuniy, 5, 1 (2019): 76-89. DOI: 10.24952/el-qonuniy.v5i1.1765.

Dyani, Vina Akfa. "Pertanggungjawaban Hukum dan Perlindungan Hukum bagi Notaris dalam Membuat Paryy Acte". Lex 
Renaissance, 2, 1 (2017): 162-76. DOI: 10.20885/JLR.vol2.iss1. art11.

Edwar, Faisal A. Rani, dan Dahlan Ali. "Kedudukan Notaris sebagai Pejabat Umum Ditinjau dari Konsep Equality Before the Law". Jurnal Hukum \& Pembangunan, 49, 1 (2019): 180-201. DOI: 10.21143/jhp.vol49.no1.1916.

Erwinsyahbana, Tengku dan Melinda. "Kewenangan dan Tanggung Jawab Notaris Pengganti setelah Pelaksanaan Tugas dan Jabatan Berakhir”. Lentera Hukum, 5, 2 (2018): 323-40. DOI: 10.19184/ eljh.v5i2.7339.

Fahri, Nur. "Digital Storage". https://nurfahri.web.ugm.ac.id/ category/pengantar-teknologi-informasi/page/6/. Diakses $17 / 4 / 2021$.

Fakhriah, Efa Laela. Bukti Elektronik dalam Sistem Pembuktian Perdata. Bandung: Refika Aditam, 2017.

Fios, Frederikus. "Keadilan Hukum Jeremy Bentham dan Relevansinya bagi Praktik Hukum Kontemporer”. Humaniora, 3, 1 (2012): 299-309. DOI: 10.21512/humaniora.v3i1.3315.

Fuady, Munir. Perbuatan Melawan Hukum. Bandung: Citra Aditya Bakti, 2002.

Hadiana, Asep Id. "Pemanfaatan Teknologi QR Code untuk Verifikasi Akta Notaris (PPAT)”. MIND Journal, 1, 1 (2016): 41-48. DOI: $10.26760 /$ mindjournal.v1i1.41.

Ilyas. "Tanggung Jawab Ahli Waris terhadap Utang Pewaris Berdasarkan Hukum Islam”. Kanun Junal Ilmu Hukum, 13, 3 (2011): 125-37.

Inshakova, Olegovna Agnessa, Ivanovich Alexander, Vitaliyevna Elena Smirenskaya, dan Vladimirovna Vladimira Dolinskaya. "Modern Communication Technologies in Notification of Notarial Actions in Russia". Journal of Advanced Research in Law and Economics, 8, 7 (2017): 2144-51. DOI: 10.14505//jarle. V8.7(29).10.

Irawan, Anang Ade, A. Rachmad Budiono, dan Herlin Wijayanti. "Pertanggungjawaban Ahli Waris Notaris sebagai Pejabat Umum atas Akta Notaris yang Menimbulkan Kerugian Para 
Pihak". Lentera Hukum, 5, 2 (2018): 341-58. DOI: 10.19184/ ejlh. v5i2.6992.

Kuswanto, Mohamat Riza dan Hari Purwadi. "Urgensi Penyimpanan Protokol Notaris dalam Bentuk Elektronik dan Kepastian Hukumnya di Indonesia”. Jurnal Repertorium, 4, 2 ( 2017): 62-69. Moeliono, Tristam P. dan Tanius Sebastian. "Tendensi Reduksionis dan Utilitarianis dalam Ilmu Hukum Indonesia: Membaca Ulang Filsafat Hukum Gustav Radbruch”. Makalah dalam Konferensi Asosiasi Filsafat Hukum Indonesia ke-5, Solo, 17-18 November 2015.

Nasution, Bahder Johan. "Kajian Filosofis tentang Konsep Keadilan dari Pemikiran Klasik sampai Pemikiran Modern”. Yustisia, 3, 2 (2014): 118-30. DOI: 10.20961/yustisia.v3i2.11106.

Nasution, Muhammad Faisal. "Tanggung Jawab Pemberi dan Penerima Protokol Notaris terhadap Protokol Notaris yang Hilang atau Rusak”. Tesis, Universitas Sumatera Utara, Medan, 2017.

Nola, Luthvi Febryka. "Upaya Perlindungan Hukum secara Terpadu bagi Tenaga Kerja Indonesia (TKI)”. Negara Hukum, 7, 1 (2016): 35-52. DOI: 10.22212/jnh.v7i1.949.

Permana R., Yofi. "Pengaturan Penyerahan Protokol Notaris yang Telah Meninggal Dunia dan Prakteknya di Sumatera Barat”. Jurnal Cendekia Hukum, 5, 1 (2019): 1-17. DOI: 10.33760/jch. v5i1.120.

Pramono, Dedy. "Kekuatan Pembuktian Akta yang Dibuat Notaris selaku Pejabat Umum Menurut Hukum Acara Perdata di Indonesia”. Lex Jurnalica, 12, 3 (2015): 248-58.

Raffles. "Tanggung Jawab dan Perlindungan Hukum Direksi dalam Pengurusan Perseroan Terbatas". Undang: Jurnal Hukum, 3, 1 (2020): 107-37. DOI: 10.22437/ujh.3.1.107-137.

Rahardjo, Satjipto. Biarkan Hukum Mengalir: Catatan Kritis tentang Pergulatan Manusia dan Hukum. Jakarta: Penerbit Kompas, 2008.

Rahardjo, Satjipto. Ilmu Hukum. Bandung: Citra Aditya Bakti, cetakan keenam, 2006.

Sahbani, Agus. "Hak Ingkar Bukan untuk Melindungi Notaris”. https:/ / www.hukumonline.com/berita/baca/ 
lt52948b592619f/hak-ingkar-bukan-untuk-lindungi-notaris/, 26/11/2013. Diakses 18/7/2019.

Sari, Devina Puspita. "Kekuatan Pembuktian Fotokopi Surat yang Tidak Dapat Dicocokkan dengan Aslinya dalam Perkara Perdata”. Undang: Jurnal Hukum, 2, 2 (2019): 323-52. DOI: 10.22437/ ujh.2.2.323-352.

Wijaya, Andes Willy. "Konsep Dasar Cyber Notary: Keabsahan Akta dalam Bentuk Elektronik", https:/ / vivajusticia.law.ugm. ac.id/2018/11/29/konsep-dasar-cyber-notary-keabsahan-aktadalam-bentuk-elektronik/, 29/11/2018. Diakses 17/4/2021.

Yulia, Aris. "Profesi Notaris di Era Industrialisasi dalam Perspektif Transendensi Pancasila”. Law and Justice, 4, 1 (2019): 56-67. DOI: 10.23917 / laj.v4i1.8045.

\section{Peraturan dan Putusan Hukum}

Republik Indonesia. Undang-undang Nomor 30 Tahun 2004 tentang Jabatan Notaris. Lembaran Negara Tahun 2004 Nomor 117, Tambahan Lembaran Negara Nomor 4432.

Republik Indonesia. Undang-undang Nomor Tahun 2006 tentang

Perlindungan Saksi dan Korban. Lembaran Negara Tahun 2006

Nomor 64, Tambahan Lembaran Negara Nomor 4635.

Republik Indonesia. Undang-undang Nomor 2 Tahun 2014 tentang

Perubahan atas Undang-undang Nomor 30 Tahun 2004 tentang Jabatan Notaris. Lembaran Negara Tahun 2014 Nomor 3, Tambahan Lembaran Negara Nomor 5491.

Republik Indonesia, Pengadilan Negeri Singaraja. Putusan Nomor 30/Pdt.G/2018/PN.Sgr, 21/11/2018, perkara perdata antara Muhammad Fadhol Indah Prasetyo lawan Yusriansyah Makaramah.

Republik Indonesia, Pengadilan Tinggi Bandung. Putusan Nomor 485/PDT/2018/PT.BDG, 28/11/2018, perkara perdata antara

A. Kosasih melawan Sudjono Barak Rimba, dkk.

Republik Indonesia, Pengadilan Tinggi Jambi. Putusan Nomor 22/PDT/2012/PT.JBI, 8/8/2012, perkara perdata antara Siti Muryani RRM Koesoema, dkk. lawan Saman, dkk. 